\title{
Factors shaping economics of land use change in Gilgit Baltistan, Pakistan
}

\author{
Amjad Ali - Ghulam Ali - Ghulam Muhammad Shah • Attaullah Shah • \\ Rehmat Karim $\cdot$ Srijana Joshi $\cdot$ Karamat Ali $\cdot$ Babar Khan
}

Accepted: 19 July 2021 / Published online: 27 July 2021

(C) The Author(s) 2021, corrected publication 2021

\begin{abstract}
Sustainable land use is one of the emergent mountain concerns which requires immediate policy and regulatory attention. This study examines land use change and land prices at three different 5-yearly intervals: 2019, 2014 and 2009 respectively in three urbanizing districts of Gilgit-Baltistan Pakistan. Empirical evidences are gathered by using mixedmethod approaches. Findings of the study suggest that households' land holdings of cultivated and uncultivated patches have declined significantly whereas, built-up area continued to rise over the years. Simultaneously, value of land in the urban centers has increased exponentially. As a result, sustainability of future economic benefits and ecosystem health becomes a major challenge for local community and policy makers. Therefore, this study recommends effective and sustainable land use planning with the
\end{abstract}

A. Ali $(\bowtie) \cdot$ R. Karim

Karakoram International University Hunza Campus,

Karimabad, Hunza, Pakistan

e-mail: Amjad.eco@kiu.edu.pk

R. Karim

e-mail: Rehmat@kiu.edu.pk

G. Ali - G. M. Shah - S. Joshi · B. Khan

International Center for Integrated Mountain

Development (ICIMOD), Lalitpur, Nepal

e-mail: ghulam.ali@icimod.org

G. M. Shah

e-mail: Ghulammuhammad.shah@icimod.org emphasis on legislation, policy making, judicious and healthy use of ecosystem services and local ownership synced with customary laws and traditional knowledge.

Keywords Gilgit-Baltistan · Land use - Land valuations $\cdot$ Market price $\cdot$ Sustainable mountain tourism

\section{Introduction}

Landscapes evolve gradually over time. The nature of land use varies depending upon local needs and prevailing physical, socio-economic, cultural and environmental conditions (Renes, 2015). Urbanization

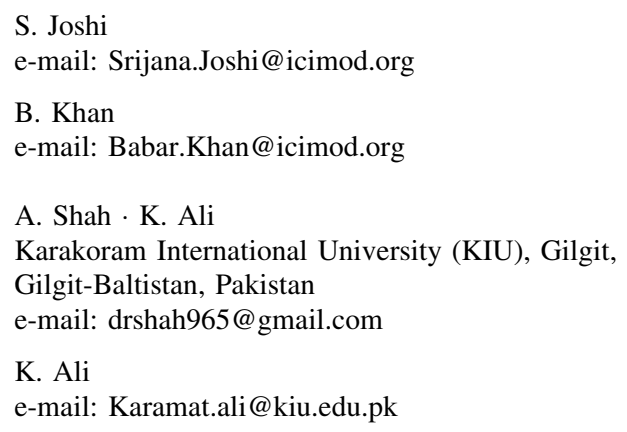


and industrialization have however, intensified landuses, around the globe but more so in the land-scarce, remote high mountain areas (Antrop, 2005, 2013), which otherwise being critical watersheds provide vital ecosystem services for human survival and wellbeing. The Hindu Kush Himalaya (HKH) harboring 35,000+ species of plants and $200+$ species, 36 global biodiversity hotspots, covering $39 \%$ of the region's total area $\left(\sim 1.6\right.$ million $\left.\mathrm{km}^{2}\right)$ source five major rivers of the world, supply freshwater, food, fiber, medicines and energy sources to about 140 million mountain people, and 1.9 billion living downstream (Wester et al., 2019). Land conversion, more often from cultivated and arable lands to commercial uses is driven by economic, political, environmental and social factors, and such conversion has significant opportunity cost in terms of biodiversity loss and land fragmentation and low agricultural productivity, creating huge challenges of food, water and energy insecurity. Location of land, ownership patterns, household size, size of landholding and income are some of the main internal drivers of land use change whereas, socioeconomic development of the region, pattern of urbanization and government policies are some of the major external factors of land use change (Firman, 1997). Tran et al., (2018) considered social, economic, and demographic factors, urbanization, technological advancement and lands use policies among the key drivers of land use change but some scholars (such as Karami et al, 2017; Tan et al., 2014) identified proximity, road networks and distance to cities, influenced the landscape change. Buying and selling of land influence land use and such transactions are heavily influenced by location, climate, availability of water, and access to transport (Ng'ayu, 2015).

In economics, land is one of the most important inputs of production. It is also considered as the most efficient income generating source which is an important determinant of economic growth (Li, 2014)). Owing to the limited nature of land supply, a competition of land use between agricultural and nonagricultural use is growing with every passing year, resulting in ultimately decline of agricultural land and thus, threatening food supply. Such conversion is more pronounced in rural parts of the developing countries (Azadi et al., 2011). Rural areas in particular mountain regions of the world have experienced drastic changes with dramatic decline in agricultural and land abandonment (MacDonald et al., 2000; Soliva et al., 2008) and currently the intensity of these changes are even more pronounced because of the socioeconomic development. These regions of the world are highly sensitive to both climatic change and anthropogenic activities (Huber et al., 2013) and these factors affect dynamics of the mountain landscape and the ecosystems services Pedrono et al., 2016). Among the anthropogenic activities, tourism development is one the main drivers of land use change. Currently tourism is more pronounced in mountain regions (Ali, 2020) but it has negative impact associated with land use change such as deforestations, decrease in agricultural land and water scarcity as also reported by StricklandMunro et al., (2010) and Niu et al., (2012). Scholars such as Verburg et al. (2009) and Hou and Cai (2004) argued that land use change influences the functions of an ecosystem, climate change and human vulnerability as well as anthropogenic and biophysical processes whereas, Wijesekara et al. (2012) and Linderman et al. (2005) were of the view that over the last several years, anthropogenic driven land use change has emerged as resulting process with regard to the environmental and climate change. The rapid unplanned urbanization in mountain regions possesses serious threat to the economic, social and environmental sustainability (Jarah et al., 2019). Understanding land use dynamics is very important in formulating proper policy for land use in the mountain regions. Often the past and present dynamics of such changes are lacking which pose serious challenges for land manager to devise effective decisions on sustainable use of the fragile mountain land (Balsiger \& Debarbieux, 2015). In such a case, understanding the current dynamics of land use change and finding ways to use sustainable use of mountainous land are need of the time.

Situated in the northern territories of Pakistan, Gilgit-Baltistan (GB), formerly known as Northern Areas of Pakistan is home to many mighty mountains including the world highest mountain ranges-the Karakoram, the Himalayas and the Hindu Kush. Administratively, Gilgit-Baltistan is constituted of ten districts which spread over an area of 72,496 sq km. Geographically, Gilgit-Baltistan borders with Afghanistan in the North-West, Jammu and Kashmir in the East, China in the North-East and Azad Jammu and Kashmir in the South East. This region being a typical high altitude mountain ecosystem is extremely fragile and prone to environmental degradation and 
loss of vital mountain ecosystem products and services. The land use change is very obvious in the region due to the rapid socioeconomic development. In order to asses and analyze the forces at play behind this land use change and to come up with a better plan for appropriate land use ensuring ecosystem health and human wellbeing is crucial. Land use change in terms of conversion of agricultural land to nonagricultural activities jeopardizes some of the most productive and important natural resources such as soil, crops, livestock, wild fruits, medicinal herbs, and timber, on which local people have historically relied upon since decades. Furthermore, such conversion also jeopardizes future leisure and tourism facilities as unsustainable land conversion may lead to change the natural landscape of region, which in turn decrease the natural attraction of the region for tourists. This study is a first ever attempt to examine the dynamics of land use change in three tourists' destinations in GilgitBaltistan Pakistan and the results provide baseline information to help land use planning and sustainable use of land in mountain areas. The specific objectives of this study are to (1) analyze the current land use practices in the three selected districts of GilgitBaltistan, Pakistan and (2) compare the economic value of cultivated, uncultivated and commercial land undergoing an unprecedented change in the history of Gilgit-Baltistan.

\section{Methodology}

Like all mountainous regions of Hindu Kush Himalaya $(\mathrm{HKH})$ region, Gilgit Baltistan (GB) is facing major issues of climate change, glacial melting, internal migration, food insecurity and natural disasters. Over the recent past years, urbanization has been highly rapid due to internal migration from rural areas, commercialization, increased tourism activities (Hussnain et al., 2020).

In view of these emerging challenges to the region, this study was conducted in selected sides of three districts of Gilgit-Baltistan namely district Ghizer, district Hunza and district Nagar (Fig. 1). In district Hunza; Karimabad, Aliabad, Gulmit and Sost were selected as these areas have witnessed urbanization and commercialization relatively higher as compare to others in the last 2-3 decades. Therefore, the respondents for both from structured questionnaire survey and FDGs represent communities who have gone through process of urbanization and commercialization thus providing informed inputs linking changes in the ecosystem services and land use change patterns.

In district Ghizer; Gahkuch and Damas were selected due to rapid internal migration and urbanization processes at in next 5-10 years. The urbanization process got catalyzed due to emerging plans to construct new roads and expressways in the area to attract domestic and international tourists. The urbanization in this case, is though relatively slower, yet the apprehensions and concerns of the people are important in terms of their lessons learnt from the district Hunza with regards to land use changes and ecosystem degradation. The third area is Hopper in district Nagar which is, relatively a rural area, representing most of the rural land now getting attuned to transformation towards changes. District Nagar holds a high potential for tourists due to famous glaciers, treks and other tourism attractions Basic facilities and infrastructure are developing relatively slow than other two sites. The study of this part of the sites, will provide a baseline for the rural areas of GB, where extensive opportunities for tourism exit, yet the understanding of the communities about the tourism and land use changes and their impacts on ESS delivery is important.

\section{Valuation approach}

The study employed market price approach to determine change in value of land over the years and ownership of the asset (land). Market price method is commonly used to determine value of ecosystem assets as Brown and Matysiak (2000) argue that market value can be considered as representative value in the case of a well-functioning market. Average price of land by category was multiplied with the average quantity of land (measured in the prevailing market unit of kanal @ 1 acre=8 kanal or one kanal $=4046 \mathrm{~m}^{2}$ ) owned by households to obtain economic worth of the respective land category. Thus, Eq. 1 was used for this purpose.

$$
\begin{aligned}
& \text { EVLijt }=(\text { Avg private Price } \text { Prit }) \\
& \times(\text { Avg Land Holding } \\
&i j t)
\end{aligned}
$$

where EVLi is the economic value of land of $i$ th category for $j$ th region, $i$ th is land category which 


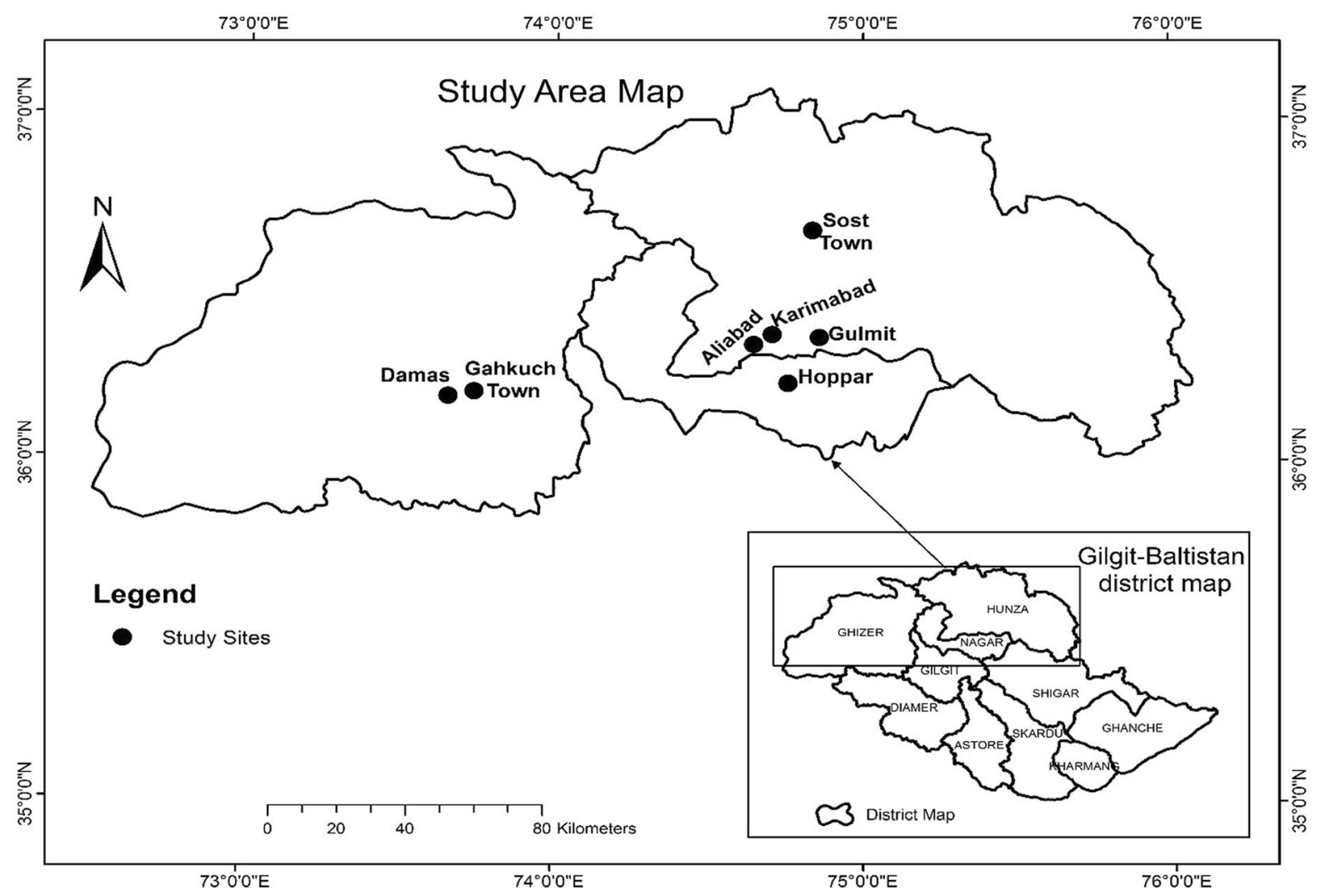

Fig. 1 Map of the study area

include cultivated land, uncultivated land and commercial land, $j$ th is the specific region where study districts are located, that is, Ghizer region, Hunza region, or Nagar region, $t$ is the time period considered to calculate value of land, that is, survey reference year, that is, 2019, 2014 and 2009. Avg Price $_{i}$ represents average private price of the respective land category, and AvgLandHolding $g_{i j t}$ is the $i$ th land category holding of household in $j$ th region for $t$ th time period.

\section{Data collection}

\section{Acquisition of satellite images and ground truth data}

In order to obtain land use change patterns over the reference years' satellite data and ancillary data was obtained using GIS tools. Ancillary data included aerial imagery of study areas and its surrounding, topographic maps and ground truth data. Satellite data for the year 2020 consisted of multi-spectral data acquired through Sentinel 2B for the month of April provided by the European Commission's Copernicus Program. Data were preprocessed using ArcMap 10.5 for geo-referencing, mosaicking and sub-setting of the image on the basis of Area of Interest (AOI). These data sets were digitized from Sentinel imagery in GIS and then corrected with higher resolution imagery in Google Earth. The delineated classes were land along main road, land along linked roads, Build-up area and orchard and Community forest. The reliability of the information was checked through ground truthing. The quality of the necessary land cover ground truth varies widely depending on the study region, the data source, available information about its creation and the spatial resolution. Ground truth/verification is important in the initial classification of an image (Foody et al., 2016). For each class, ground-truth polygons were digitized based on field experienced and visual analysis of locations on Google Maps. 


\section{Household survey}

Based on the images obtained through satellite images and ground truth data, villages showing high land use change patterns over the reference years were selected in each district to obtain land value data. A total of seven such villages were identified in the target districts located in the study areas. In this regard, primary data was collected using a structured household survey questionnaire and the sample size was calculated using confidence level of $95 \%$ and margin of error \pm 5 from each sampled districts and in this way we obtained 405 households as our total size thus, we obtained 405 households. However, 355 households responded to the questionnaire making the response rate of survey $87.65 \%$ (Table 1). The Sampled households were selected using simple random sampling technique and for this purpose, lists of all households in the respective villages were developed with the help of Local Support Organization (LSO) and then households were selected randomly from the lists. LSOs are community owned, and community led organizations at grassroots level (Union Council) established by Aga Khan Rural Support Program (AKRSP) in the region. Household survey questionnaire included indicators related to ownership of land by the household by type of land, economic value of land given the reference years, and indicators related to changes in land use type.

During the household survey, respondents were asked to report the current price (2019) of per kanal of their cultivated, uncultivated and commercial land. In order to get the reliable data on the land categories for the year 2014 (5 years back) and 2009 (10 years back), respondents were asked whether they had sold or purchased any type of land (cultivated, uncultivated or commercial) during the years 2019, 2014 and 2009 and if the reply was yes, then then they were asked to report the sale/purchase price of that land category. In order to validate the prices of land categories, village representatives were also consulted and confirm the land prices obtained during households' survey. To get average price for a particular land category in a sampled village, the prices of the particular land category got from household survey in a village were summed and divided by the number of households who reported the price of a particular land category. This way the average private prices of land categories were determined and are reported in Tables 4, 5 and 6. The survey was conducted during November-December 2019 .

\section{Secondary data}

Secondary data on land prices by type were also collected from land revenue department maintained by the office of the Assistant Commissioner, in each of the target districts. These offices are the mandated public offices responsible for keeping and maintaining land revenue data usually updated every third year. The land revenue department reports only fixed government price for the various land categories of land as reported in Tables 4, 5 and 6 under the heading of Govt. price. For some villages, government prices were not found as marked 'N/A' in Tables 4, 5 and 6.

Table 1 Sample size for primary data collection

\begin{tabular}{llll}
\hline District name & Village name & No of HH proposed in the survey & No of HH responded for the survey \\
\hline Hunza & Aliabad & 95 & 90 \\
& Karimabad & 47 & 41 \\
& Gulmit & 46 & 41 \\
& Sost & 42 & 40 \\
Ghizer & Damas & 49 & 40 \\
& Gakuch & 72 & 65 \\
Nagar & Hopper & 54 & 38 \\
& Total & 405 & 355 \\
\hline
\end{tabular}


Focus group discussion (FGDs)

In each of the sampled village, one focus group discussion was conducted to add qualitative nuance to the patterns of land use change revealed by the household survey.Total seven FGDs were conducted in the sampled villages as shown in Fig. 1. FGDs play an important role in qualitative research, where the important questions are placed before the experts from the concerned fields. According to Krueger and Casey (2000), 6-8 is the most optimal size for FGD, which is easy to handle by the moderator. In the FGD, 8 experts were selected from the Government departments, community representatives and political parties. At least $25 \%$ were selected as females. The discussion was professionally moderated. For discussion, structured questions and pre-planned probes were administered in line with Krueger and Casey (2000). For structured discussions, hourglass design is used as per the Fig. 2. The two-way focus group discussion method was used, in which two groups were used. One group actively discussed the issues and the other groups observed and raised questions. The typical parts of the FGD, included introduction by the moderator, welcoming the participants and requesting them to introduce themselves. This is followed by the opening question, which is normally simple, so that the participants can feel comfortable.

Design of structured discussion and the role of the moderator is very important in the FGDs, as the knowledge and background of the moderator plays a
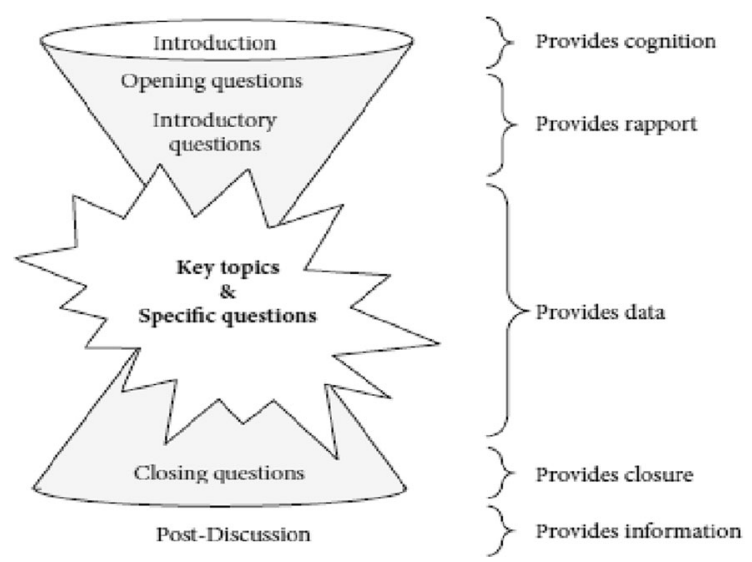

Fig. 2 Hourglass design of focal group discussions (Hennink, 2011) crucial role in creating a positive and conducive environment for discussions (Hennink et al., 2011).

In each village, village representative (called Nambardar in local language) was first conducted to nominate around 10-12 local residents for FGD who could discuss land use pattern and land pricing. The nominees were then conducted for their participation in the FGD and fortunately majority of the nominee were participated in the discussion. The discussion group included both male and female but the participation of female was relatively low in each FGD. In each FGD, 7-10 participants age above 18 were participated and each FGD took around 90 min to complete. The researcher themselves moderated each FGD and before starting the FGD, participants were informed about the nature and objectives of the discussion and their participation consent was confirmed. Prior to the FGDs, a detailed check list of questions was prepared for focused group discussions keeping in view the study objectives. The check list consisted of questions related to current and past land use patterns, households' ownership of various land categories, price and change in price of various categories of land over the time, factors causing land use, town planning and legislation etc. The data of FGDs was recorded and later it was analyzed using thematic approach and it involved in-depth analysis of various issues related land use change, sustainable land use and the government and private prices of various categories of land.

\section{Results}

Socio-economic characteristics of respondents

Socioeconomic characteristics of the households are reported in Table 2. It is found that the main sectors contributing as the income source is government and private sector employment, which accommodates $48.58 \%$ of respondents, followed by self-employment/businesses contributing $36.17 \%$ as income source. Likewise, rent from assets like land and houses are also a key source of income with the share of $4.08 \%$, followed by remittances with the contribution of $3.19 \%$. Agriculture is also an important income source and it contributes around $8 \%$. Occupations of the respondents of the study have shown that majority of the respondents $(27.61 \%)$ are associated with 
Table 2 Sociodemographic characteristics of respondents

\begin{tabular}{|c|c|c|c|}
\hline Variables & Descriptions & Freq & Percentage \\
\hline \multirow[t]{2}{*}{ Gender } & Male & 256 & 72 \\
\hline & Female & 99 & 28 \\
\hline \multirow[t]{5}{*}{ Households source of income } & Employment Govt and Pvt & 274 & 48.58 \\
\hline & Self-employment (business, trade etc.) & 204 & 36.17 \\
\hline & Rent (land/houses etc.) & 23 & 4.08 \\
\hline & Remittances & 18 & 3.19 \\
\hline & Agriculture & 45 & 7.98 \\
\hline \multirow[t]{7}{*}{ Occupations of the respondents } & Farmer & 33 & 9.3 \\
\hline & Business & 94 & 26.48 \\
\hline & Housewife & 88 & 24.79 \\
\hline & Govt/Private Job & 98 & 27.61 \\
\hline & Craft work & 3 & 0.85 \\
\hline & Mason & 12 & 3.38 \\
\hline & Other & 27 & 7.61 \\
\hline \multirow[t]{8}{*}{ Education level of respondents } & No formal education & 115 & 32.4 \\
\hline & Middle (8-year) & 57 & 16.1 \\
\hline & Matric (10-year) & 62 & 17.5 \\
\hline & FA/FSc/Icom (12-year) & 39 & 11 \\
\hline & Primary (5-year) & 28 & 7.9 \\
\hline & BA/BSc (14-year) & 27 & 7.6 \\
\hline & Masters (16-year) & 25 & 7 \\
\hline & Other & 2 & 0.6 \\
\hline \multirow[t]{6}{*}{ Household size } & $2-4$ members & 42 & 11.58 \\
\hline & 5-7 members & 143 & 40.4 \\
\hline & $8-10$ members & 92 & 25.99 \\
\hline & 11-13 members & 39 & 11.02 \\
\hline & 14-16 members & 21 & 5.93 \\
\hline & Above 16 & 18 & 5.08 \\
\hline Average household size & 8.8 & & \\
\hline
\end{tabular}

is confirmed that $66.39 \%$ households have family members ranging between 5 and 10 .

\section{Current land use}

Table 3 depicts the current land use composition in the sampled villages. The types of land available in the sample villages could be mainly characterized into four main categories including smallholding along the main road, and link roads, built-up, and associated orchard area, and forest area owned by the individual households. Mountain farmers mostly engage in subsistence farming on the smallholdings they own where they usually grow a mix of crops to meet the livelihood and food needs of themselves and their 
Table 3 Current land use composition

\begin{tabular}{|c|c|c|c|c|c|c|c|c|c|c|}
\hline \multirow[t]{2}{*}{ District } & \multirow[t]{2}{*}{ Village } & \multirow[t]{2}{*}{$\begin{array}{l}\text { Total cover } \\
\text { area (ha) }\end{array}$} & \multicolumn{2}{|c|}{$\begin{array}{l}\text { Smallholding along } \\
\text { main roads }\end{array}$} & \multicolumn{2}{|c|}{$\begin{array}{l}\text { Smallholding along } \\
\text { linked roads }\end{array}$} & \multicolumn{2}{|c|}{$\begin{array}{l}\text { Built-up, associated } \\
\text { orchard area }\end{array}$} & \multicolumn{2}{|c|}{$\begin{array}{l}\text { Forest area owned by } \\
\text { the households }\end{array}$} \\
\hline & & & Area (ha) & $\%$ & Area (ha) & $\%$ & Area (ha) & $\%$ & Area (ha) & $\%$ \\
\hline \multirow[t]{4}{*}{ Hunza } & Aliabad & 491.8 & 81.3 & 16.3 & 24.2 & 5 & 230.6 & 46.7 & 155.7 & 31.9 \\
\hline & Karimabad & 390.8 & 69.7 & 17.5 & 28.2 & 7.2 & 166.5 & 42.6 & 126.3 & 32.4 \\
\hline & Gulmit & 486.6 & 87.2 & 17.9 & 41.7 & 8.6 & 269.4 & 55.4 & 88.2 & 18.1 \\
\hline & Sost & 187.4 & 33.9 & 18.1 & 72.5 & 38.7 & 36.5 & 19.5 & 44.5 & 23.8 \\
\hline \multirow[t]{2}{*}{ Ghizer } & Gahkuch & 2206.4 & 244.5 & 11.4 & 377.2 & 14.8 & 1165.3 & 54.3 & 419.4 & 19.5 \\
\hline & Damass & 402 & 81.2 & 20.2 & 35.7 & 8.9 & 256.8 & 63.9 & 28.3 & 7 \\
\hline Nagar & Hoper & 187.4 & 14.6 & 7.7 & 8.3 & 4.4 & 133.7 & 71.4 & 30.8 & 16.4 \\
\hline Total & 4354.4 & 613.4 & $14.10 \%$ & 588.8 & $13.50 \%$ & 2260.8 & $52 \%$ & 893.2 & $20.50 \%$ & \\
\hline
\end{tabular}

families. The built-up areas and associated orchard areas mainly consists of a covered area surrounding a building, usually with a protected wall, and with some fruit-and-non-fruit trees grown in the premises.

In terms of overall land cover area, Ghakuch is found to be the largest with 2206.4 hectares of overall land, followed by Aliabad covering an overall area of 491.8 hectares, Gulmit covering an overall area of 486.6, and Damas covering an overall area of 402 hectares. Whereas, the sample village Hoper, and Sost are found to be similar in terms of overall cover area that is constituted of 187.4 hectares, and smallest in terms of cover area. However, the sample village Hoper is found to have highest built-up, associated orchard area compare to other sample villages. The village Sost, on the other hand, despite having covered area similar to Hoper, is found to be the least village with built-up and orchard area.

The overall current composition of sample villages for three district is such that $14.1 \%$ is linked with main road, $13.5 \%$ for the smaller link roads (villages' arteries), built up and orchard (52\%) and community/farm forestry $(20.5 \%)$ as shown in Table 3 . The value of land around the main road and link road tend to be higher due to increased commercial activities. Whereas reduction in orchards and increase in built up area is apparent, more likely and rapid. The most noticeable change from the study villages that: Aliabad being linked with the main road has expanded very quickly with expected further extension due to expected urbanization and commercialization of the area. Aliabad and Karimabad are most commercially advanced due to trade and tourism among the chosen site. Sost, being the most important villages from trade and tourism show interesting phenomenon that a significant portion is linked to main road and it is lowest in buildup and agriculture, but interestingly the private forest as compared to overall land is higher. Gahkuch has comparatively less land linked with main road otherwise, it has more built up and agriculture significance. The pattern of Damas is interesting. Around $29 \%$ of land is linked with main road and link roads with $64 \%$ built up and agriculture. Gahkuch and Damas are potential destinations of commercial and tourism attractions. The proposed express way from Gilgit to Shandur pass and Chitral will attract high number of national and international tourists. Hoper is also showing a fascinating combination of land linked to roads and emerging built up and agriculture. However due to poor infrastructure and lack of civic amenities, the district is not commercializing with the same pace like Karimabad and Gahkuch. This is a

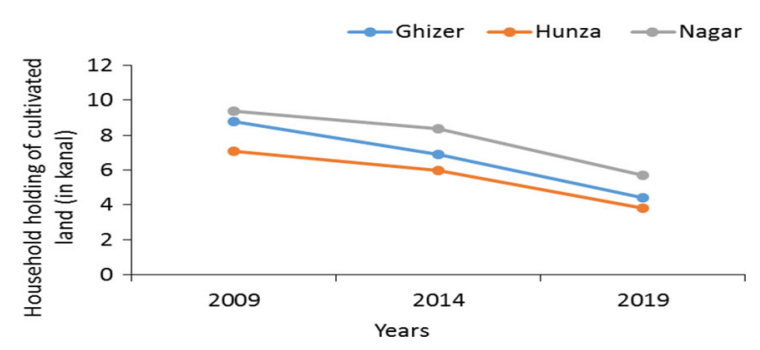

Fig. 3 Household cultivated landholding 
common problem with the rural areas of the GB in attracting tourists and ultimately, the burden of domestic and international tourisms is concentrated in few hotspots.

\section{Change in land holding/ownership over the time}

In order to know the land ownership over the time, respondents were asked during the household survey to mention the ownership of cultivated land in 2014 and 2019, 5-year back and 10-year back and responses are analyzed in Fig. 3. In the case of District Ghizer, the households' ownership of cultivated land tends to decrease over the time as the average cultivated land of a household was 8.8 kanal (10-year back), 6.9 kanal (5-year back) and it is $4.4 \mathrm{kanal}$ in 2019. This can be attributed to increase of population and sale of land to others. Similar trend is found for other two districts as evident in Fig. 3. In the case of households' holding of uncultivated land similar declining trend is observed as shown Fig. 4. However, households' holding of commercial land tends to increase marginally in all the three Districts and as evident in Fig. 5.

In terms of comparative analysis, over the past 5-year period (2014-2019), households' holding of cultivated land has decreased by around $36.67 \%$ in District Hunza, 36.23\% in District Ghizer and 32.14\% in District Nagar. Since Hunza and Ghizer are pronounced to having more commercial activities as compared to district Nagar and thus, this could be the main reason that declining of cultivated land in Hunza and Ghizer is more. Further, the declining of uncultivated land which is highest in District Nagar $(27.93 \%)$ as compared to the other two sampled districts i.e. $22.22 \%$ in Hunza and $14.28 \%$ in Ghizer. However, increasing pattern is observed in the case of commercial land (mostly in the form of build-up area) as the increase of commercial land holding is more pronounced in Ghizer (77.77\%) follow by Nagar

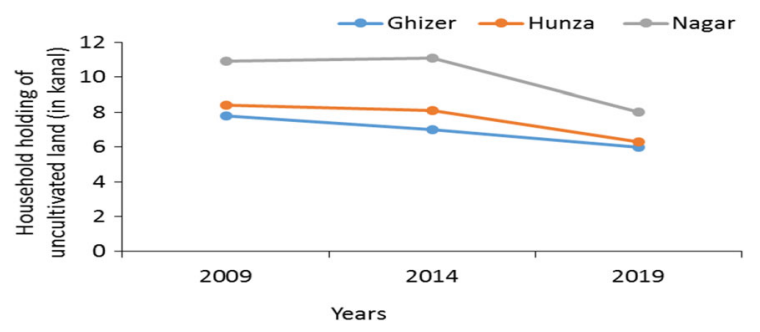

Fig. 4 Household uncultivated landholding

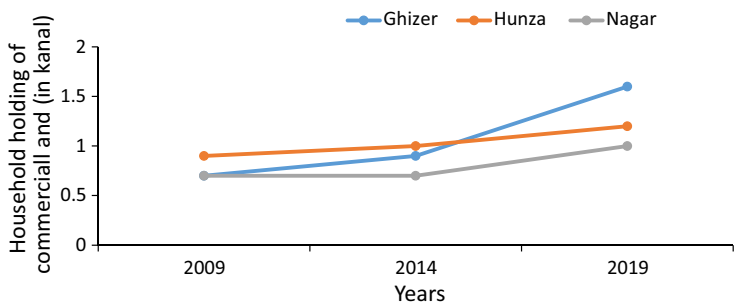

Fig. 5 Commercial landholding

(42.85\%) and Hunza (33.33\%) over the last 5-year period.

It can be inferred from this analysis households tend to convert their cultivated and uncultivated into commercial land by constructing buildings for hotels, guest houses, house for rent and other commercial use of land. This conversion can be justified that the inflow of tourists has been increasing significantly over the last 5 years due to improved law and order situation in Gilgit-Baltistan and special attention of present government on tourism sector development in Pakistan (Ali \& Yousuf, 2019; Ali, 2020; Baig \& Hussain, 2020). Increase in tourism has generated opportunities of allied businesses. Hence local communities tend to start constructing buildings for hotels, shopping centers and other commercial centers.

Change in land value over time

Market prices and government fixed prices of cultivated land for each village are reported in Table 4. Based on the revenue record, the Government prices of land are normally fixed at the average cost of land sale after every 3 years. At time, this price is not the true indicator of the market price and private transactions on buying and selling of land take place on prices significantly higher than the government price. The study reveals that in the case of Aliabad Hunza, per kanal private price of cultivated land was PKR 3.58 million in 2019. However, for the same year, Government of Gilgit-Baltistan has fixed per kanal price of cultivated land in Aliabad as PKR 2.0 million which is significantly lower than the private prices of cultivated land. Similar trends are found in all other village of the study. Location and type of the land, reason of selling land and many other factors influence the price of land. This study therefore, considers the average prices of cultivated land reported in household's survey in the same villages. 
Table 4 Price of per kanal cultivated land (values in million PKR)

\begin{tabular}{|c|c|c|c|c|c|c|}
\hline \multirow[t]{2}{*}{ Villages } & \multicolumn{2}{|l|}{2019} & \multicolumn{2}{|l|}{2014} & \multicolumn{2}{|l|}{2009} \\
\hline & Private price & Govt. price & Private price & Govt. price & Private price & Govt. price \\
\hline Aliabad & 3.58 & 2 & 2.1 & 0.72 & 1.28 & 0.36 \\
\hline Karimabad & 2.92 & 2 & 1.88 & 0.65 & 1.2 & 0.36 \\
\hline Hopper & 1.29 & 1.1 & 0.81 & 0.7 & 0.4 & N/A \\
\hline Sost & 2.07 & 1 & 1.03 & 0.44 & 0.49 & 0.29 \\
\hline Damasi & 1.64 & 1.3 & 1.03 & 0.96 & 0.68 & N/A \\
\hline Gakhcuh & 2.48 & 2.5 & 1.63 & 1.9 & 1.23 & N/A \\
\hline Gulmit & 1.53 & 1 & 0.8 & 0.44 & 0.4 & 0.29 \\
\hline
\end{tabular}

Table 5 Per kanal price of uncultivated land (figures in million PKR)

\begin{tabular}{|c|c|c|c|c|c|c|}
\hline \multirow[t]{2}{*}{ Villages } & \multicolumn{2}{|l|}{2019} & \multicolumn{2}{|l|}{2014} & \multicolumn{2}{|l|}{2009} \\
\hline & Private price & Govt. price & Private price & Govt. price & Private price & Govt. PRICE \\
\hline Aliabad & 1.54 & 1.25 & 0.65 & 0.36 & 0.3 & 0.18 \\
\hline Karimabad & 0.45 & 1 & 0.31 & 0.32 & 0.21 & 0.18 \\
\hline Hopper & 0.6 & 0.55 & 0.45 & 0.35 & 0.27 & N/A \\
\hline Sost & 1.52 & 0.4 & 0.81 & 0.22 & 0.3 & N/A \\
\hline Damasi & 1 & 0.65 & 0.44 & 0.48 & 0.24 & N/A \\
\hline Gakhcuh & 1.46 & 1.25 & 0.97 & 0.95 & 0.66 & N/A \\
\hline Gulmit & 0.45 & 0.4 & 0.25 & 0.22 & 0.2 & 0.18 \\
\hline
\end{tabular}

This analysis reveals that there is significant difference between price of cultivated land fixed by the government and market prices (the price at which buying and selling between individuals take place). The high private prices of land are due to high demand of land in the region as the demand pressure of land puts prices of land upward.

The prices of per kanal of uncultivated land are reported in Table 5 and the results show that in Aliabad, market price of per kanal uncultivated land is PKR 1.54 million in 2019 whereas, in 2014 (5-years back) it was 0.65 million and 10 years back it was 0.30 million. However, the government of Gilgit-Baltistan has fixed per kanal price of uncultivated price significantly lower than the private price as shown in Table 5. This analysis shows that the prices of uncultivated land in all the samples villages have been increasing significantly over the time.
The price of per kanal commercial land fixed by government of Gilgit-Baltistan for Aliabad is PKR 4.35 million whereas, market price of the same land in the same village is PKR 6.23 million. Similar govt. prices for commercial land (per kanal) for Karimabad is PKR 4.25 million whereas, the same land has price of PKR 6.5 million in private sector. Such huge differences are also observed in other villages as evident in Table 6.

Figure 6 shows the valuation of cultivated land, uncultivated and commercial land for the three the three period interval in the sampled districts. For District Hunza it is found that economic value of cultivated land for per households remained PKR 10.557 million for the year 2019 whereas, 5 -year back it was PKR 9.823 million and 10-year back it was PKR 5.612 million. Similarly, the value of cultivated land for district Ghizer remained PKR 6.481 million, 6.812 million and 4.97 million for the years 2019, 2014 and 
Table 6 Per kanal price of commercial land (figures in millions PKR)

\begin{tabular}{|c|c|c|c|c|c|c|}
\hline \multirow[t]{2}{*}{ Villages } & \multicolumn{2}{|l|}{2019} & \multicolumn{2}{|l|}{2014} & \multicolumn{2}{|l|}{2009} \\
\hline & Private price & Govt. price & Private price & Govt. price & Private price & Govt. price \\
\hline Aliabad & 6.23 & 4.35 & 3.6 & 1.45 & 2.58 & 0.58 \\
\hline Karimabad & 6.5 & 4.25 & 3.76 & 1.04 & 2.9 & 0.58 \\
\hline Hopper & 0.85 & N/A & 0.38 & N/A & 0.2 & N/A \\
\hline Sost & 2.77 & 1.5 & 1.05 & 0.75 & 0.83 & 0.5 \\
\hline Damasi & 2.57 & 2 & 1.02 & N/A & 0.45 & N/A \\
\hline Gakhcuh & 4.83 & 3.5 & 3.36 & 2.4 & 2.43 & N/A \\
\hline Gulmit & 3.5 & 1.5 & 1.41 & 0.8 & 0.83 & 0.5 \\
\hline
\end{tabular}

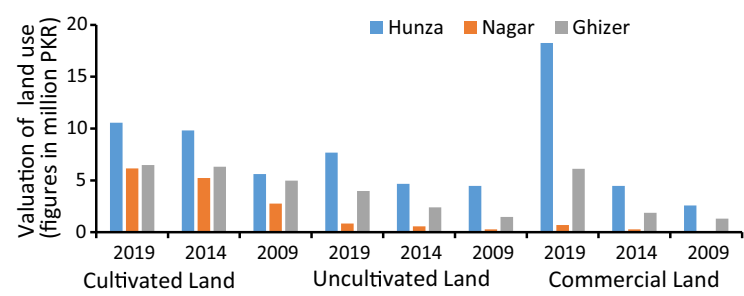

Fig. 6 Valuation of land use categories

2009 respectively. This analysis reveals that the values of all categories of land have increased over the time but such increased is more pronounced in district Hunza as compared to other two districts evident in Fig. 6.

\section{Analysis of FGDs}

Focus group discussions were also conducted to add qualitative nuance to the patterns revealed by the respondents during household survey and to establish explanations for these patterns. From the focused group discussions, it was found that land use change is certainly fast and its effects are visible across all study areas. The intensity of the change from cultivated and uncultivated into built up is highly significant though varies from district to district but certainly land used change is the most certain and common phenomenon. The land use change was observed in terms of conversion of cultivated and uncultivated land into construction of concrete buildings in an unsustainable way. One of FGD participants in Karimbad Hunza aged 35 male said:
"Over the last ten years, land use change is very obvious in our district as people are converting their cultivated and uncultivated into build up area of hotel, restaurant and guest houses in order to meet the growing tourists demand in the region".

Another participant in Gahkuch Ghizer (aged 47, male) was of the view:

"Owing to the current socioeconomic and infrastructure development, people have now left agricultural activities and depend on market for their food. The ownership and possession of household agricultural land tends to decrease owing to the construction of building and most of the buildings are being used for commercial purpose. Currently we are facing shortage of organic food which once we used to grow from our own land"

In comparing the focused discussion across districts, it was revealed that in District Hunza, and Ghizer, construction of build-up areas for commercial purposes are growing exponentially as compared to Nagar, without following any proper town planning codes and building bylaws and hence individuals are at freedom to use the land, as they want. The apathy is the building are also built without any consideration to climate, ecosystem services and civic amenities. Due to the leapfrog development the Planning and investment for infrastructural facilities such as electricity, water supply, sewerage system, transportation network, irrigation channels, and solid waste management are found disarrayed or unorganized. This 
unplanned construction carries a huge opportunity cost in terms of loss in biodiversity and ecosystem services there by threatening their ability of provision, protection and regulation. Moreover, it is further revealed that there is significant difference among the attitude of people in three study areas Hunza, Hoper and Ghizer towards selling of land. In Hunza people sell their lands to gain from high market prices due to locational advantage. Same trend is also highlighted in Ghizer by the stakeholders in focus group discussion. Whereas in Hoper Nagar, it was revealed that people have totally different attitude towards land selling and community is committed to retain their land holdings for their future generation. One of the FGD participants in Nagar said:

"In our village, we have agreed unanimously that we will not sale our land to outsiders but to retain our land for our future generation. We have learnt from the situation in Hunza that over commercialization wit ill-planning brings more social, economic and environmental issues so we are planning accordingly".

Most of the community members during FGDs ascertained that traditionally, barren land was only used for construction and fields were only used for agriculture. Logic being to produce enough cereal crops to meet basic food security and also to maintain balanced natural ecosystem health such as use of water, pasture, soil and agrobiodiversity. They said that socially, selling land to aliens has been a big taboo in particular in Hunza. However, overtime, they observed that temptation of commercial and economic gains has changed old perceptions and people are selling land now easily and construction of building in agricultural fields is seen as common phenomenon. They further added that traditional and tribal institutions roles have diminished and new form of institutions included government and market have taken over but there is big gap of communication and coordination for integrated and sustainable land use planning. Therefore, the transition is haphazard and not well planned. Households' ownership of cultivated and uncultivated land is decreasing sharply whereas buildup area is increasing at a significant pace all over. All these changes have implication for household and societies.

Participants of the discussions were also asked to discuss the prices of various categories of land and from their discussions it was found that on average in each districts, every 5-year, significant increase in market price of land is being witnessed. However, this trend is more pronounced in Hunza district due to its locational advantage on Karakoram Highway (KKH). The attributed factors highlighted by the FGD participants for increase in price include: increase in population leading to increase for housing, commercial needs in particular to respond to emerging opportunities from tourism, trade and urbanization. In the absence of proper land use regulations, local people are investing more in buildings like hotels, restaurant, café etc. for their obvious high Rate of Return on Interment (ROI). A significant flow of capital and investors from other cities is caused spiked the prices, as many people expressed their thoughts during FGDs. In many cases, local people in Hunza and Ghizer tend to sell their land to non-local people who pay significantly higher prices than locals for the land. Such local people prefer to migrate to the down part the country in Rawalpindi, Islamabad and Karachi etc. In the long term, this migration of the locals, will create serious demographic issue.

\section{Discussions}

This study found that the land use change in terms of conversion of cultivated and uncultivated land into construction of concrete buildings bring the challenge of livelihoods, food and nutrition security. The primary causes of such land conversation are the current tourism development, improvement in infrastructure and socioeconomic development of the region. This study also found that the current unplanned land use change is fast and its effects are visible across all study areas. Increasing population with increased housing needs from day by day dividing and squeezing land among families is yet another important reason. In addition, the increased off farm income sources in particular from increased tourism opportunities dovetails major shift from agriculture to commercial triggering productivity and return on asset debate. Our results of and land conversion are in line with the results of many scholars such as Mao et al. (2014) who determined that the development of tourism in Guilin China is associated with the increasing demand for build-up area and the expansion of construction area unnecessarily suggests 
the loss of ecological land. Azadi et al. (2011) examined and compared the drivers of agricultural land conversion in developed and developing countries and found that the conversion of agriculture land into nonagricultural activities is comparatively high in developing countries. Rai et al. (1994) found that the land use change from forest to other purposes has been widespread in the Himalayan region and such conversion is ultimately leads to environmental degradation. Furthermore, Trotter et. al (2017), Tran et al. (2017) found that the conversion of land surface into build area has significant impact on the air quality, temperature and relative humidity. Chaudhary et al. (2017) found that in Phobjekha valley of Bhutan the area of forest declined by $2 \%$ and marsh by $7 \%$ over the 32 -year period. Our study confirmed form focused group discussions that unplanned land use practices, unsustainable tourism development, ill-planned infrastructure development and climate change are leading drivers of change in the region and such observations are also in line with the results of past studies such as EEA (2006), Furst et al. (2011) and Maxwell et al., 2016).

This study argues that current tourism development and rapid urbanization in the sampled areas have tremendous pressure on the value of land. For instance, in sampled districts, investors from outside Gilgit-Baltistan (non-local) are now investing in tourism and related activities and such investments are more obvious in the Hunza and Ghizer. The nonlocal investors pay significant higher price for a piece of land than the local investors making upward pressure on the land prices. It was also learnt from the FGDs that with sale of land to the people from outside, causing a serious issue of the land ownership of locals-might surface. This will also threaten the culture of the region, as GB is also home to unique cultures and traditions. Another major factors is the that Hunza is gate way to China Pakistan Economic Corridor (CPEC) and this corridor has further strengthened the tourism development through infrastructure development and this results is also in line with the argument of Baig and Zehra (2020). CPEC, will no doubt multiply the opportunities of socioeconomic development for the people along the route, yet with more commercial activities and monetization, the fragile ecosystem and land resource of the region is threatened. The key challenges faced by mountain community in Gilgit-Baltistan arising from the current land use change pattern which consequently lead to reduction in agricultural and timber production, shortage of water, landscape degradation and loss in mountain biodiversity. Globally, such challenges are well documented in literature (e.g. Beniston, 2012; MacDonald et al., 2000; Mann, 2013; Soliva, 2007; Streifenede et al., 2007; Zimmermann et al., 2010). Furthermore, such challenges also cause the emigration of economically active population of the region (Messerli et al., 2011) and consequently causing flight of human capital.

Implications of unplanned land use are many and detrimental. The first and foremost on ecosystem services, food, water and energy security, and overall asset value deterioration in longer run. If same pattern persists then sustainability of the eco system remains a major challenge. The mountain ecosystems are under serious pressures in providing agriculture, forest, water, air and others basic requirements of the communities (Li et al., 2007; Liu et al., 2005). Since the supply of land is fixed whereas, growing population leads to increase in demand for land and consequently it builds upward pressure on land prices in the region. The rapid changes in land use limit the potential of ecosystem services and their sustainability and consequently degradation of natural environment and ecosystem (Laurance, 1999; Portela \& Rademacher, 2001). The natural landscape has always been influenced and modified through anthropogenic activities at different scale and extents (Gill \& Malamud, 2017; Otto et al., 2007), as reported in the FDs. Population growth and intensification of agriculture are the leading factors that determine relationship between human and land use (Eziz et al., 2010). Further, the unsustainable land use trends have serious impact on the agricultural productivity and livelihoods alternates. The trends of commercialization are reported to change the use of land and its price.

This study argues for close collaboration between community and government for legislation and policy making on land use, skills based education of the youth and preservation of local culture and value systems. The zest of the study emphasis indicates role of government towards a proper legislation and empowerment of local ownership of land and land use protocols for land zoning based town planning and sustainable land use. Gilgit-Baltistan needs a policy framework to ensure an adequate infrastructure, policy provision, encouragement to environmental friendly 
investments, knowledge and technology transfer and above all abiding by traditional and legal best practices of land use. Few countries in the world have developed mountain specific laws and policies and in the absence of such laws, mountain issues are managed and addressed through sectoral legislation related to land. Such laws and policies are developed in negotiation with a focus of lowland and thus, pay little or even no attention to the mountain specific ecosystem services and the needs of mountain community. In most cases, such polices remained ineffective in mountain regions. Therefore, to ensure sustainable land use in mountain regions, the voices of mountain communities must be heard and mountain people should be recognized as stakeholders of equal importance in policy making.

\section{Conclusion}

Rapid urbanization, intensification of economic activities with mass tourism and ambitious projects like CPEC and similar projects with intense anthropogenic activities are placing tremendous pressure on land use in mountain regions in particular in Gilgit Baltistan, Pakistan. A visible pattern of conversion of cultivated and uncultivated land into built up area indicate decrease in households' holding of cultivated and uncultivated land whereas, marginal increase in commercial land holding. In addition, built up area is emerging without any proper planning. Sustainability and resilient solutions to the future needs including: health of ecosystems, landscape management, cultural preservation, contextual climate needs, and local ownership, legal, policy and regulatory considerations are absent. Implications of unplanned land use are to hit harder in future. There is critical link of forest, water, air and other regulatory, provisioning and cultural services with agricultural, livelihoods and wellbeing of the people. This link is also missing while planning land use change, particularly, the integration of land use change with food, water, energy and ecosystem. Unsustainable tourism with current pattern may cause abandoning of the destination at any point in time - an opportunity cost which locals cannot afford. Looking at tourism and CPEC external flow of capital, ideas and investors into Gilgit-Baltistan causes huge changes in market forces at play in particular raising price of the land to an exorbitant extent.
Collaboration between community and policy makers plays a vital role in ensuring the success of land management and such collaboration enhance the community ownership in policy formulation as well as promote community involvement which consequently help in finding out the endogenous solution to land management problem. Such collaboration will also help both policy makers and community to agree on sustainable solutions in the region including addressing legal, market and community gaps as well addressing ecosystem health concerns. The sustainability of the future of the economics of the region lies in retaining healthy ecology with a balance of economics with community ownership. Since, in the study areas, urbanization is in a rapid pace, therefore town planning and urban planning may be undertaken on priority.

Acknowledgements The study was carried out under the Hindu Kush Karakoram Pamir Landscape Conservation and Development Initiative (HKPLCDI) of the International Centre for Integrated Mountain Development (ICIMOD).

Author Contributions Conceptualization, AA, GA, GMS; Methodology, AA, GM, KA; Survey Data Collection, AA, RK, KA; Original draft preparation, AA, GA, GM, KA; Review and editing, AU, SJ, GA, GM. BK. All authors have read and agreed to submit the manuscript for publication. (AA: Amjad Ali, GA: Ghulam Ali, GMS: Ghulam Muhammad Shah, AU: Attaullah Shah, KA: Karamat Ali, SJ: Srijana Joshi, RK: Rehmat Karim; BK: Babar Khan).

Funding The authors gratefully acknowledge the support of core donors of ICIMOD: the governments of Afghanistan, Australia, Austria, Bangladesh, Bhutan, China, India, Myanmar, Nepal, Norway, Pakistan, Sweden, Switzerland, and the United Kingdom.

Availability of data and materials The datasets used and/or analyzed during the current study are available from the corresponding author on a reasonable request.

\section{Declarations}

Conflict of Interest The authors declare no conflict of interest.

Open Access This article is licensed under a Creative Commons Attribution 4.0 International License, which permits use, sharing, adaptation, distribution and reproduction in any medium or format, as long as you give appropriate credit to the original author(s) and the source, provide a link to the Creative Commons licence, and indicate if changes were made. The images or other third party material in this article are included in the article's Creative Commons licence, unless indicated otherwise in a credit line to the material. If material is not 
included in the article's Creative Commons licence and your intended use is not permitted by statutory regulation or exceeds the permitted use, you will need to obtain permission directly from the copyright holder. To view a copy of this licence, visit http://creativecommons.org/licenses/by/4.0/.

\section{References}

Ali, A. (2020). Residents' attitude and perception toward impact of mountain tourism in Gilgit- Baltistan Pakistan. Journal of Public Affairs. https://doi.org/10.1002/pa.2577

Ali, A., \& Yousuf, S. (2019). Social capital and entrepreneurial intention: empirical evidence from rural community of Pakistan. Journal of Global Entrepreneurship Research. https://doi.org/10.1186/s40497-019-0193-z

Antrop, M. (2005). Why landscapes of the past are important for the future. Landscape and Urban Planning, 70(1-2), 21-34. https://doi.org/10.1016/j.landurbplan.2003.10.002

Antrop, M. (2013). A brief history of landscape research The multiple meanings of landscape. The routledge companion to landscape studies, pp. 1-15.

Azadi, H., Ho, P., \& Hasfiati, L. (2011). Agricultural land conversion drivers: A comparison between less developed developing and developed countries. Land Degradation and Development, 22(6), 596-604.

Baig, S., \& Hussain, H. (2020). Do shocks have permanent or transitory effects on tourist inflow? An application of stationarity test with structural breaks: Evidence reexamined for Gilgit-Baltistan, Pakistan. Asia Pacific Journal of Tourism Research, 25(2), 120-130. https://doi.org/10. 1080/10941665.2019.1684961

Balsiger, J., \& Debarbieux, B. (2015). Should mountains (really) matter in science and policy? Environmental Science and Policy, 49, 1-7. https://doi.org/10.1016/j.envsci.2015. 03.015

Beniston, M. (2012). Impacts of climatic change on water and associated economic activities in the Swiss Alps. Journal of Hydrology, 412-413, 291-296. https://doi.org/10.1016/ j.jhydrol.2010.06.046

Brown, G. R., \& Matysiak, G. (2000). Real estate investment: A capital market approach. https://www.pearson.com/uk/ educators/higher-education-educators/program/BrownReal-Estate-Investment-A-Capital-Market-Approach/ PGM524946.html

Chaudhary, S., Tshering, D., Phuntsho, T., Uddin, K., Shakya, B., \& Chettri, N. (2017). Impact of land cover change on a mountain ecosystem and its services: Case study from the Phobjikha valley Bhutan. Ecosystem Health and Sustainability, 3(9), 1393314. https://doi.org/10.1080/20964129. 2017.1393314

EEA. (2006). Biogeographical regions in Europe. The alpine region-Mountains of Europe. Report: 1-52. Sweden: European Environment Agency.

Eziz, M., Yimit, H., Mohammad, A., \& Zhifang, H. (2010). Oasis land-use change and its effects on the oasis ecoenvironment in Keriya Oasis, China. International Journal of Sustainable Development and World Ecology, 17(3), 244-252. https://doi.org/10.1080/13504500903211871

Firman, T. (1997). Land conversion and urban development in the northern region pf west Java Indonesia. Urban Studies, 34(7), 1027-1046.

Foody, G. M., Pal, M., Rocchini, D., Garzon-Lopez, C. X., \& Bastin, L. (2016). The sensitivity of mapping methods to reference data quality: Training supervised image classifications with imperfect reference data. ISPRS International Journal Geo-Information, 5(11), 199.

Furst, C., Lorz, C., \& Makeschin, F. (2011). Integrating land management and land cover classess to assess impacts of land use change on ecosystem services. International Journal of Biodiversity Science, Ecosystem Services and Management, 7(3), 168-181. https://doi.org/10.1080/ 21513732.2011.611119

Gill, J. C., \& Malamud, B. D. (2017). Anthropogenic processes, natural hazards, and interactions in a multi-hazard framework. Earth-Science Reviews, 166, 246-269. https://doi. org/10.1016/j.earscirev.2017.01.002

Hennink, M., Hutter, I., \& Bailey, A. (2011). Qualitative research methods. Sage Publications.

Hou, L., \& Cai, Y. (2004). An essential analysis and review on land use/cover change research. Progress in Geography, 23(6), 96-104.

Huber, R., Bugmann, H., Buttler, A., \& Rigling, A. (2013). Sustainable land-use practices in European mountain regions under global change: An integrated research approach. Ecology and Society. https://doi.org/10.5751/ ES-05375-180337

Hussnain, M. Q. ul, Waheed, A., Wakil, K., Pettit, C. J., Hussain, E., Naeem, M. A., \& Anjum, G. A. (2020). Shaping up the Future Spatial Plans for Urban Areas in Pakistan. Sustainability, 12(10), 4216. MDPI AG. Retrieved from https://doi.org/10.3390/su12104216

Jarah, S., Zhou, B., Abdullah, R., Lu, Y., \& Yu, W. (2019). Urbanization and urban sprawl issues in city structure: A case of the sulaymaniah iraqi kurdistan region. Sustainability, 11(2), 1-21.

Karami, S., Ghafary, M., Hejazi, S. M., Fakhrayee, A., \& Choulandeim, H. K. (2017). Investigating the factors underlying cities' physical growth: Evidence from the city of Rasht. Cogent Social Science, 3, 1-14.

Krueger, R. A., \& Casey, M. A. (2000). Focus groups: A practical guide for applied researchers ( $3 \mathrm{rd}$ ed.). Thousand Oaks, CA: Sage.

Laurance, W. F. (1999). Laurance 1999-tropical deforestation.pdf. 91, 109-117. www.elsevier.com/locate/biocon

Li, J. (2014). Land sale venue and economic growth path: Evidence from China's urban land market. Habitat International, 41, 307-313.

Li, R. Q., Dong, M., Cui, J. Y., Zhang, L. L., Cui, Q. G., \& He, W. M. (2007). Quantification of the impact of land-use changes on ecosystem services: A case study in Pingbian county China. Environmental Monitoring and Assessment, 128(1-3), 503-510. https://doi.org/10.1007/s10661-0069344-0

Linderman, M. A., An, L., Bearer, St., He, G., Ouyang, Z., \& Liu, J. (2005). Modeling the spatial-temporal dynamics and 
interactions of households, landscapes, and giant panda habitat. Ecological Modelling, 183(1), 47-65.

Liu, J., Tian, H., Liu, M., Zhuang, D., Melillo, J. M., \& Zhang, Z. (2005). China's changing landscape during the 1990s: Large-scale land transformations estimated with satellite data. Geophysical Research Letters, 32(2), 1-5. https://doi. org/10.1029/2004GL021649

MacDonald, D., Crabtree, J., Wiesinger, G., Dax, T., Stamou, N., Fleury, P., Lazpita, J. G., \& Gibon, A. (2000). Agricultural abandonment in mountain areas of Europe: Environmental consequences and policy response. Journal of Environmental Management, 59(1), 47-69.

Mann, S. (2013). The future of mountain agriculture. In Stefan Mann (Ed.), The future of mountain agriculture (pp. 1-176). Springer.

Mao, X., Meng, J., \& Wang, Q. (2014). Modeling the effects of tourism and land regulation on land-use change in tourist regions: A case study of the Lijiang River Basin in Guilin China. Land Use Policy, 41, 368-377.

Maxwell, S. L., Fuller, R. A., Brooks, T. M., \& Watson, J. E. (2016). Biodiversity: The ravages of gungs, nets and bulldozers. Nature, 536(7615), 143-145. https://doi.org/ 10.1038/536143a

Messerli, P., Scheurer, T., \& Veit, H. (2011). Between longing and flight-migratory processes in mountain areas, particularly in the European Alps: Context of contributions to this issue and outlook. Revue De Geographie Alpine, 99(1), $1-4$.

Ng'ayu, M. M. (2015). What are the drivers of growth on the rural-urban fringes? A Case Study of the Nairobi-Kiambu Corridor. Journal Emerging Trends in Economics \& Management Sciences, 6(6), 414-431.

Niu, L., Cheng, Z., \& Zhao, M. (2012). Ecological characteristics of species in the different vegetation landscape districts with tourism disturbance in Wutai Mountains. Journal of Mountain Science, 30(3), 282-289.

Otto, R., Krüsi, B. O., \& Kienast, F. (2007). Degradation of an arid coastal landscape in relation to land use changes in Southern Tenerife (Canary Islands). Journal of Arid Environments, 70(3), 527-539. https://doi.org/10.1016/j. jaridenv.2007.02.001

Pedrono, M., Locatelli, B., Ezzine-de-Blas, D., Pesche, D., Morand, S., \& Binot, A. (2016). Impact of climate change on ecosystem services. In E. Torquebiau (Ed.), Climate change and agriculture worldwide (pp. 251-261). Springer.

Portela, R., \& Rademacher, I. (2001). A dynamic model of patterns of deforestation and their effect on the ability of the Brazilian Amazonia to provide ecosystem services. Ecological Modelling, 143(1-2), 115-146. https://doi.org/ 10.1016/S0304-3800(01)00359-3

Rai, S. C., Sharma, E., \& Sundriyal, R. C. (1994). Conservation in the Sikkim Himalaya: traditional knowledge and land use of the Mamlay watershed. Environmental Conservation, 21, 30-34.

Renes, H. (2015). Historic landscapes without history? A reconsideration of the concept of traditional landscapes. Rural Landscapes: Society, Environment, History, 2(1), $1-11$.
Soliva, R. (2007). Agricultural decline, landscape change, and outmigration: Debating the sustainability of three scenarios for a Swiss mountain region. Mountain Research and Development, 27(2), 124-129. https://doi.org/10.1659/ mrd.0907

Soliva, R., Rønningen, K., Bella, I., Bezak, P., Cooper, T., Flø, B. E., Marty, P., \& Potter, C. (2008). Envisioning upland futures: Stakeholder responses to scenarios for Europe's mountain landscapes. Journal of Rural Studies, 24(1), 56-71.

Streifenede, T., Tappeiner, U., Ruffini, F. V., Tappeiner, G., \& Hoffmann, C. (2007). Selected aspects of agro-structural change within the alps. Revue de Géographie Alpinel Journal of Alpine Research., 95(3), 41-52.

Strickland-Munro, J. K., Allison, H. E., \& Moore, S. A. (2010). Using resilience concepts to investigate the impacts of protected area tourism on communities. Annals Tourism Research, 37(2), 499-519.

Tan, R. H., Liu, Y. L., Liu, Y. F., He, Q. S., Ming, L. C., \& Tang, S. H. (2014). Urban growth and its determinants across the Wuhan urban agglomeration, central China. Habitat Interntional, 44, 268-281.

Tran, D. X., Pla, F., Latorre-Carmona, P., Myint, S. W., Caetano, M., \& Kieu, H. (2017). Characterizing the relationship between land use land cover change and land surface temperature. ISPRS-Journal of Photogrammetry Remote Sensing, 124, 119-132.

Tran, H., Nguyen, Q., \& Kervyn, M. (2018). Factors influencing people's knowledge, attitude and practice in land use dynamics: A case study in $\mathrm{Ca}$ Mau province in the Mekong delta Vietnam. Land Use Policy, 72(2018), 227-238.

Trotter, L., Dewan, A., \& Robinson, T. (2017). Effects of rapid urbanization on the urban thermal environment between 1990 and 2011 in Dhaka Megacity Bangladesh. AIMS Environment Science, 4(1), 145-167.

Verburg, P. H., Jeannette van de Steeg, A., \& Veldkamp, L. W. (2009). From land cover change to land function dynamics: A major challenge to improve land characterization. Journal of Environmental Management, 90(3), 1327-1335.

Wester, P., Mishra, A., Mukherji, A., \& Shrestha, A. B. (2019). The Hindu Kush Himalaya assessment: Mountains sustainability and people. Springer International Publishing.

Wijesekara, G. N., Gupta, A., Valeo, C., Hasbani, J. G., Qiao, Y., Delaney, P., \& Marceau, D. J. (2012). Assessing the impact of future land-use changes on hydrological processes in the Elbow River watershed in southern Alberta Canada. Journal of Hydrology, 412-413, 220-232.

Zimmermann, P., Tasser, E., Leitinger, G., \& Tappeiner, U. (2010). Effects of land-use and land-cover pattern on landscape-scale biodiversity in the European Alps. Agriculture, Ecosystems and Environment, 139(1-2), 13-22. https://doi.org/10.1016/j.agee.2010.06.010

Publisher's Note Springer Nature remains neutral with regard to jurisdictional claims in published maps and institutional affiliations. 